\title{
Quality Parameters and Bioactive Compounds of Red Tomatoes (Solanum lycopersicum L.) cv Roma VF at Different Postharvest Conditions
}

\author{
María Lorena Luna-Guevara ${ }^{1}$, Óscar Jiménez-González ${ }^{1}$, Juan José Luna-Guevara ${ }^{1}$, Paola Hernández-Carranza ${ }^{1}$ \\ \& Carlos Enrique Ochoa-Velasco ${ }^{2}$ \\ ${ }^{1}$ Colegio de Ingeniería en Alimentos, Facultad de Ingeniería Química, Benemérita Universidad Autónoma de \\ Puebla, Puebla, México \\ ${ }^{2}$ Colegio de Ingeniería Agroindustrial, Facultad de Ingeniería Química, Benemérita Universidad Autónoma de \\ Puebla, Puebla, México \\ Correspondence: Carlos Enrique Ochoa-Velasco, Colegio de Ingeniería Agroindustrial. Facultad de Ingeniería \\ Química, Benemérita Universidad Autónoma de Puebla, Puebla, México. Tel: 52-222-295-500. E-mail: \\ carlosenriqueov@hotmail.com
}

Received: April 18, 2014 Accepted: June 14, 2014 Online Published: June 16, 2014

doi:10.5539/jfr.v3n5p8 URL: http://dx.doi.org/10.5539/jfr.v3n5p8

\begin{abstract}
Tomato is one of the most important crops at worldwide; however, much of the production is lost during the postharvest due to the inadequate storage conditions. The aim of this study was to evaluate the effects of different postharvest conditions on some quality and bioactive parameters of tomatoes. Tomatoes Roma VF variety were stored at three temperature $\left(7,22\right.$, and $\left.37^{\circ} \mathrm{C}\right)$ to evaluate some physicochemical characteristics ( $\mathrm{pH}$, total soluble solids, titratable acidity, color, and firmness) and bioactive compounds (vitamin $\mathrm{C}$, lycopene, carotenoids, and antioxidant activity) during five days; time in which tomato change from physiological to edible maturity. The $a$ color parameter increased significantly $(\mathrm{p}<0.05)$ at the storage temperature of 22 and $37^{\circ} \mathrm{C}$. The firmness was higher in tomato stored at $7{ }^{\circ} \mathrm{C}$ after 5 days, while at $37{ }^{\circ} \mathrm{C}$ the firmness decrease in $8 \%$. Tomatoes stored at $22{ }^{\circ} \mathrm{C}$ showed a decrease of chlorophyll $a$ and $b$, reaching the maximum lycopene $(31.7 \pm 1.5$ $\mathrm{mg} / \mathrm{kg}$ fresh weight) and carotenoids contents $\left(118.7 \pm 0.1 \mu \mathrm{g} / 100 \mathrm{~g}\right.$ fresh weight), while at 7 and $37^{\circ} \mathrm{C}$ the chlorophyll $a$ did not change during the storage. However, the vitamin $\mathrm{C}$ was higher in tomatoes stored at 7 and $37{ }^{\circ} \mathrm{C}$. The antioxidant activity remains constant during the time of storage, regardless the temperature. The storage temperature of $22{ }^{\circ} \mathrm{C}$ not affected significantly $(\mathrm{p}<0.05)$ the color and firmness of tomatoes, at the same temperature, the bioactive compounds (carotenoid, vitamin $\mathrm{C}$, and antioxidant activity) presented highly correlated with the developments of the red color.
\end{abstract}

Keywords: antioxidant activity, bioactive compounds, temperature, tomatoes

\section{Introduction}

Tomato (Solanum lycopersicum L.) is one of the most important crop vegetable and also one of the most commercialized and industrialized (Ogwulumba, Ugwuoke, \& Omemaramadu, 2011). In 2012, the SIAP informed, that tomato production in Mexico reached 2, 838, 369.87 tons, with a national yield of 51.38 ton/ha. Puebla, Mexico had a production around 52.85 tons; however, the yield was 63.58 ton/ha. The SAGARPA in 2009 pointed out, that in the northwest of Puebla the tomato crop under greenhouse was increased during the past decade. This suggests that the greenhouse tomatoes are preferred by the consumers because of its good quality, either if it's sold fresh or processed (Kubota, Thomson, \& Javanmardi, 2006).

Tomatoes has been considered an important source of bioactive compounds, such as, vitamins (principally vitamin C and vitamin E), carotenoids (lycopene), and phenolic compounds like flavonoids (Ketsa \& Wongveerakhan, 1987; Giovanelli, Lavelli, Peri, \& Nobili, 1999; Raffo, Leonardi, Fogliano, Ambrosino, Salucci, \& Gennaro, 2002), which provide phytonutrients to the diet that are associated with the prevention of chronic degenerative diseases, like cardiovascular and carcinogenic diseases (Willcox, Catignani, \& Lazarus, 2003). According to the FAO (1979) one tomato provides $40 \%$ of vitamin C (ascorbic acid) and $20 \%$ of vitamin A, of the recommended daily intake; also provides significant amount of potassium, fiber, calcium, iron, and small 
amounts of magnesium, thiamine, riboflavin, and niacin.

Color and firmness are important quality factors of tomato; the red color comes from pigments like carotenoids, which develop during ripening and storage; these compounds are synthesized from chlorophyll degradation (Satyan \& Patwardhan, 1983). Moreover, firmness is affected by the storage conditions, postharvest handling, and the enzymatic activity (Kader, Stevens, Albright-Holton, Morris, \& Algazi, 1977). Other quality attributes of tomatoes are associated with the physicochemical characteristics, such as, total soluble solids, $\mathrm{pH}$, weight, and organic acids (Kader et al., 1977). During the ripening and storage of tomatoes occur several desirable changes, such as, increasing the flavor and aroma compounds, increasing the ratio between citric to malic acid; and also, the ascorbic acid, phenolic compounds, and flavonoids are increased (Leonardi, Ambrosino, Esposito, \& Fogliano, 2000; Toor \& Savage, 2006). Nevertheless, if the storage conditions are inadequate the tomatoes could present undesirable characteristics and nutrient composition (Javanmardi \& Kubota, 2006).

To extend the shelf life of tomato it is important to reduce the oxidative metabolism by storing at low temperature, in combination with modified atmosphere (especially at high concentration of carbon dioxide). However, storage of tomatoes at critical low temperatures predisposes them to chilling injury (Toor \& Savage, 2006). Therefore, the aim of this research was to evaluate the effects of the postharvest conditions on the quality parameters and bioactive compounds of tomato Roma VF variety.

\section{Materials and Methods}

\subsection{Tomato Samples}

Tomatoes (Solanum lycopersicum L.) cv Roma VF were grown in fertiirrigation greenhouse located in Sierra Norte of Puebla, Mexico, during the fall-winter season, 2012. Tomatoes were sorted free from physical and microbiological damages; the physiological maturity was 5 (light red color) according to color chart of USDA (1997). Tomatoes were recollected (one day before the beginning of the storage), washed with distilled water, and the excess of water was eliminated with absorbent paper.

\subsection{Storage Conditions}

Tomatoes were randomly sorted and divided in 3 batches. The tomatoes were stored at $7{ }^{\circ} \mathrm{C}(90 \% \mathrm{RH})$ in a refrigerator (TAPPAN EUR251p7w6, Ohio, USA); $22(40 \% \mathrm{RH})$ and $37{ }^{\circ} \mathrm{C}(60 \% \mathrm{RH})$ in a controlled temperature camera (Electro tech systems, inc, model 5518, PA, USA). The quality characteristics and bioactive compounds were evaluated after 1,3 , and 5 days of storage, during this time the tomatoes change from physiological maturity to edible maturity.

\subsection{Physicochemical Characteristics}

The $\mathrm{pH}$, total soluble solids ( $\left.{ }^{\circ} \mathrm{Brix}\right)$, and titratable acidity (\% citric acid) were evaluated according to the 981.12 , 932.12, and 942.15 AOAC (2000) methods, respectively.

\subsection{Color}

Three tomatoes of each storage condition were used to evaluate the $L$ (luminosity, white-black), $a$ (red-green), and $b$ (yellow-blue) color parameters, in the Hunter scale, using a Colorflex M 6405 (Virginia, USA) colorimeter in the reflectance mode. The evaluation was made in the equatorial zone of each tomato (Arias, Lee, Specca, \& Janes, 2000).

\subsection{Firmness}

The firmness was evaluated in the equatorial zone of each tomato using a penetrometer TE model ST32 (FO, Italia). The tomato was compressed $2 \mathrm{~mm}$ in depth, using a conical plate at a speed of $5 \mathrm{~mm} / \mathrm{s}$ (Arias et al., 2000).

\subsection{Ascorbic Acid}

The ascorbic acid (vitamin C) was evaluated with the ascorbate oxidase activity, according to the Foyer, Rowell and Walker (1983) methodology with modifications. $0.1 \mathrm{~g}$ of tomato was mixed with percloric acid (1M) (JT Baker, Avantor Perfomance Materials, PA, USA) during $1 \mathrm{~min}$. The solution was centrifuged at $5000 \mathrm{rpm}\left(4^{\circ} \mathrm{C}\right)$ during $20 \mathrm{~min}$. The supernatant was taken and the $\mathrm{pH}$ was adjusting to 4.5 with a buffer solution of sodium phosphate (pH 7.6), the solution was centrifuged again. $200 \mu \mathrm{L}$ of the stock solution was mixed with $140 \mu \mathrm{L}$ of buffer solution and $20 \mu \mathrm{L}$ of DDT (ditioriol $0.077 \mathrm{~g} / \mathrm{mL}$ ) (Sigma-Aldrich, Toluca, Mexico). The mix was stored at room temperature in darkness during $30 \mathrm{~min}$. Moreover, $400 \mu \mathrm{L}$ of the stock solution was taken and mixed with $1600 \mu \mathrm{L}$ of EDTA solution $(0.380 \mathrm{~g} / 100 \mathrm{~mL}$ of sodium phosphate buffer) (Fermont, Monterrey, Mexico), and $40 \mu \mathrm{L}$ of L-ascorbate oxidase enzyme (Sigma-Aldrich, Toluca, Mexico). The absorbance was measured after 
$30 \mathrm{~min}$ at $265 \mathrm{~nm}$ using a UV-Visible Jenway spectrophotometer model 6405 (Staffordshire, UK). The ascorbic acid was calculated using the next equation:

$$
\mathrm{AA}=\left[\left(\mathrm{A}_{\mathrm{i}}-\mathrm{A}_{\mathrm{f}}\right) * \mathrm{EC}\right]^{*} \mathrm{MW} * 100
$$

Where $A A$ is the ascorbic acid content (mg of ascorbic acid/100 $\mathrm{g}$ of sample), $A_{i}$ is the initial absorbance, $A_{f}$ is the final absorbance, $E C$ is the extinct coefficient (12.8), $M W$ is the molecular weight of ascorbic acid (176.1 $\mathrm{g} / \mathrm{gmol})$.

\subsection{Lycopene}

The lycopene concentration was evaluated according to the Sadler and Dezman (1990) methodology. One g of tomato was homogenized with $1 \mathrm{~mL}$ of distilled water; then, an aliquot (0.4-0.6 g) of the homogenized was mixed with a solution of hexane/acetone/ethanol (2:1:1) (JT Baker, PA, USA) and BHT $0.05 \%(\mathrm{w} / \mathrm{v})$ (Sigma-Aldrich, MO, USA), the mixed was stored at room temperature in a dark environment. The samples were agitated to $180 \mathrm{rpm}$ during $30 \mathrm{~min}$, and then $10 \mathrm{~mL}$ of distilled water were added. After the total phase's separation (15 $\mathrm{min})$, the absorbance of nonpolar phase was evaluated at $472 \mathrm{~nm}$, using a hexane as blank. The lycopene content was calculated using the next equations:

$$
\begin{aligned}
& \mathrm{TS}=\frac{(\mathrm{ITS} * \mathrm{HTS})}{(\mathrm{ITS}+1)} \\
& \left.\mathrm{LC}=\frac{(\mathrm{Abs} * \mathrm{EC})}{\mathrm{TS}}\right)
\end{aligned}
$$

where TS is the tissue sample (g), ITS is the initial tomato sample (g), HTS is the homogenized tomato sample (g), $L C$ is the lycopene content (mg of lycopene/kg of sample), $E C$ is the extinct coefficient (31.2).

\subsection{Chlorophylls and Carotenoids}

The carotenoids content was evaluated according to the Lichtenthaler and Wellbum (1983) methodology. One $g$ of tomato pulp was macerated with $5 \mathrm{~mL}$ of acetone solution $(80 \% \mathrm{v} / \mathrm{v}), 2 \mathrm{~g}$ of calcium carbonate (Meyer, Edo. de México, México) and $2 \mathrm{~g}$ of sea sand; the mixed was centrifuged at $3500 \mathrm{rpm}$ at room temperature during 10 min. The absorbance was evaluated at 470,645 , and $662 \mathrm{~nm}$ to evaluate the chlorophyll $a$ and $b$, and total carotenoid. Acetone was used as a blank and the calculated of carotenoids was using the next equation:

$$
\begin{gathered}
\mathrm{C}_{\mathrm{a}}=11.75 \mathrm{Abs}_{662}-2.350 \mathrm{Abs}_{645} \\
\mathrm{C}_{\mathrm{b}}=18.61 \mathrm{Abs}_{645}-3.96 \mathrm{Abs}_{662} \\
\mathrm{C}_{\mathrm{c}}=\frac{1000 \mathrm{Abs}{ }_{470}-2.27 \mathrm{C}_{\mathrm{a}}-\left(81.4 \mathrm{C}_{\mathrm{b}}\right)}{227}
\end{gathered}
$$

where $A b s$ is the absorbance, $C a$ is the chlorophyll $a, C b$ is the chlorophyll $b$, and $C c$ is the carotenoid content ( $\mu \mathrm{g}$ of carotenoids/100 $\mathrm{g}$ of sample).

\subsection{Antioxidant Activity}

Antioxidant activity was evaluated by the DPPH radical (1,1-diphenyl-2-picrylhydrazyl) according to the Mongkolsilp, Pongbupakit, Sae-Lee, and Sitthithaworn (2004) method. To obtain the tomato extract; six g of tomato pulp (fresh weight) was mixed with $30 \mathrm{~mL}$ of methanol: water solution $(80: 20 \% \mathrm{v} / \mathrm{v})$. The mixed was agitated at $125 \mathrm{rpm}$ during 12 hours at $40{ }^{\circ} \mathrm{C}$. Two $\mathrm{mL}$ of DPPH radical $(0.1 \mathrm{mM})$ (Sigma-Aldrich, MO, USA) was mixed with $500 \mu \mathrm{L}$ of extract and was stored for 30 min at darkness. The absorbance was measured at 517 $\mathrm{nm}$ using methanol as blank. The inhibition percentages and antioxidant activity [Trolox Equivalent Antioxidant Activity (TEAC)] were calculated using the next equations:

$$
\begin{gathered}
\mathrm{I}=\frac{\left(\mathrm{Abs}_{\mathrm{b}}-\mathrm{Abs}_{\mathrm{s}}\right)}{\mathrm{Abs}_{\mathrm{s}}} * 100 \\
A A=\left(\frac{I-b}{m}\right) * 100
\end{gathered}
$$

where $I$ is the inhibition (\%), $A b s_{b}$ is the absorbance of blank, and $A b s_{s}$ is the absorbance of the methanol extract, $A A$ is the amount of Trolox ( $\mu \mathrm{M}$ TEAC/100 $\mathrm{g}), m$ is the slope (4084.2 $\mathrm{g} / \mu \mathrm{M}$ TEAC), and $b$ is the intercept 
$(1246.6 \%)$ of the standard curve $\left(\mathrm{R}^{2}=0.98\right)$.

\subsection{Statistical Analysis}

The Microsoft Excel Program (Microsoft Inc. Redmond, WA) was used to calculate averages and Pearson correlations. The analysis of variance (ANOVA) was performed using the Minitab 15 program (Minitab Inc. PA, USA, 2008). Differences between treatments were analyzed by Tukey's pairwise mean comparisons $(\alpha=0.05)$.

\section{Results and Discussions}

\subsection{Physicochemical Characteristics}

Table 1 presents the physicochemical characteristics of tomatoes during the storage at different conditions. The total soluble solids were constant during the five days of storage. Wold, Rosenfeld, Holte, Baugerød, Blomhoff, and Haffner (2004) reported similar values of total soluble solids (4.9 to 5.7\%). During 8 days of storage at 15.4 to $16.2{ }^{\circ} \mathrm{C}$; Tigist, Workneh, and Woldetsadik (2013) pointed out that total soluble solids of tomatoes Roma VF variety were constant (4.1 to 4.3). Arias et al. (2000) reported similar values of $\mathrm{pH}(4.0)$ to those obtained in this study. The $\mathrm{pH}$ of tomatoes stored at 7 and $22{ }^{\circ} \mathrm{C}$ did not significantly changed $(\mathrm{p}>0.05)$; while at $37{ }^{\circ} \mathrm{C}$, the $\mathrm{pH}$ was increased $(\mathrm{p}<0.05)$. Gómez and Camelo (2002) reported that during the storage of tomatoes in controlled atmosphere $\left(12{ }^{\circ} \mathrm{C}\right)$, the $\mathrm{pH}$ slightly increased. In general, the titratable acidity was $0.3 \pm 0.0 \%$ (citric acid), and was under the reported by other researchers, like Wold et al. (2004); they informed a titratable acidity of $0.44-0.77 \%$. During the storage, titratable acidity of tomatoes stored at $7{ }^{\circ} \mathrm{C}$ did not change significantly $(\mathrm{p}>$ $0.05)$. However, in tomatoes stored at 22 and $37^{\circ} \mathrm{C}$, the titratable acidity significantly decreased $(\mathrm{p}<0.05)$ after 5 and 3 days, respectively. Both, $\mathrm{pH}$ and titratable acidity are based on organic acids presents in tomatoes; generally the organic acids decrease during the storage, because they are used as substrate in the respiration process, which increases with increasing the temperature of storage (Wills, Lee, Graham, McGlasson, \& Halls, 1981).

Table 1. Physicochemical characteristics of tomato during the storage ${ }^{a}$

\begin{tabular}{|c|c|c|c|c|c|c|c|c|c|}
\hline \multirow{2}{*}{ Time (d) } & \multicolumn{3}{|c|}{ Total soluble solids $(\%)$} & \multicolumn{3}{|c|}{$\mathrm{pH}$} & \multicolumn{3}{|c|}{ Titratable acidity $^{\mathrm{b}}$} \\
\hline & $7^{\circ} \mathrm{C}$ & $22^{\circ} \mathrm{C}$ & $37^{\circ} \mathrm{C}$ & $7^{\circ} \mathrm{C}$ & $22^{\circ} \mathrm{C}$ & $37^{\circ} \mathrm{C}$ & $7^{\circ} \mathrm{C}$ & $22^{\circ} \mathrm{C}$ & $37^{\circ} \mathrm{C}$ \\
\hline 0 & $3.9 \pm 1_{\mathrm{a}}$ & $3.9 \pm 1_{\mathrm{a}}$ & $3.9 \pm 1_{\mathrm{a}}$ & $4.1 \pm 0_{\mathrm{a}}$ & $4.1 \pm 0_{\mathrm{a}}$ & $4.1 \pm 0_{\mathrm{a}}$ & $0.3 \pm 0_{\mathrm{a}}$ & $0.3 \pm 0_{\mathrm{a}}$ & $0.3 \pm 0_{\mathrm{a}}$ \\
\hline 1 & $3.3 \pm 0_{\mathrm{a}}$ & $3.5 \pm 0_{\mathrm{a}}$ & $3.7 \pm 0_{\mathrm{a}}$ & $4.0 \pm 0_{\mathrm{a}}$ & $4.0 \pm 0 \mathrm{a}$ & $4.2 \pm 0_{\mathrm{ab}}$ & $0.3 \pm 0_{\mathrm{a}}$ & $0.3 \pm 0_{\mathrm{a}}$ & $0.3 \pm 0_{\mathrm{a}}$ \\
\hline 3 & $3.9 \pm 1_{\mathrm{a}}$ & $3.8 \pm 1_{\mathrm{a}}$ & $3.7 \pm 1_{\mathrm{a}}$ & $4.0 \pm 0_{\mathrm{a}}$ & $4.1 \pm 0_{\mathrm{a}}$ & $4.3 \pm 0_{\mathrm{ab}}$ & $0.3 \pm 0_{\mathrm{a}}$ & $0.2 \pm 0_{\mathrm{a}}$ & $0.2 \pm 0_{\mathrm{b}}$ \\
\hline 5 & $3.8 \pm 0_{\mathrm{a}}$ & $3.6 \pm 0_{\mathrm{a}}$ & $4.4 \pm 1_{\mathrm{a}}$ & $4.2 \pm 0_{\mathrm{a}}$ & $4.1 \pm 0_{\mathrm{a}}$ & $4.4 \pm 0_{\mathrm{b}}$ & $0.3 \pm 0_{\mathrm{a}}$ & $0.2 \pm 0_{\mathrm{b}}$ & $0.2 \pm 0_{\mathrm{b}}$ \\
\hline
\end{tabular}

$\bar{a}$ Average $(\mathrm{n}=3) \pm$ Standard deviation. Different letters within the same column indicate significant difference (p $<0.05)$.

$\mathrm{b}_{\%}$ citric acid.

\subsection{Color}

Figure 1 presents the $L, a$, and $b$ color parameters of tomatoes during the storage at different conditions. The $L, a$, and $b$ color parameters at the beginning of the storage were $37 \pm 2,21.7 \pm 2.5$, and $24 \pm 1$, respectively. Similar values were reported by Arias et al. (2000) from tomato cv. Laura. They informed that the $L, a$, and $b$ values were $41 \pm 0.4,22 \pm 0.5$, and $24 \pm 0.4$, respectively. De Souza, Scalon, Chitarra, and Chitarra (1999) pointed out that in tomatoes the $L$ and $a$ color parameters were related to lycopene concentration; however, the correlation of lycopene with $b$ value was poorly. The $L$ color parameter did not significantly changed $(\mathrm{p}>0.05)$ during the storage at different temperatures. However, increasing the storage temperature reduces the luminosity $(L)$, which indicating a darkening of tomatoes. The most important color parameter in tomato is the $a$ (red-green) color, which significantly increased $(\mathrm{p}<0.05)$ at $22{ }^{\circ} \mathrm{C}$, this could be due to the ripeness and senescence process of the fruit and the increased synthesis of lycopene; at storage temperatures of 7 and $37{ }^{\circ} \mathrm{C}$ did not exist changes $(\mathrm{p}>$ 0.05 ) of the $a$ color. Žnidarčič, Dan, Oplanić, and Karić (2010) pointed out that during the storage of tomato (cv. Belle), red color showed higher increase with increasing the storage temperature. The $b$ color parameter significantly $(\mathrm{p}<0.05)$ increased at $7{ }^{\circ} \mathrm{C}$, which indicate an increase of yellow color; this could be probably due to the chilling injury (De Castro, Vigneault, Charles, \& Cortez, 2005) or due to the synthesis of flavonoids pigments, like quercentin (Crozier, Lean, McDonald, \& Black, 1997). The total color change was not 
significantly $(\mathrm{p}>0.05)$ affected by the storage temperature; at the end of the storage, the total color change in tomatoes were $5.8 \pm 1.3,6.1 \pm 1.9$, and $5.6 \pm 2.0$ to the storage temperature of 7,22 , and $37{ }^{\circ} \mathrm{C}$, respectively.

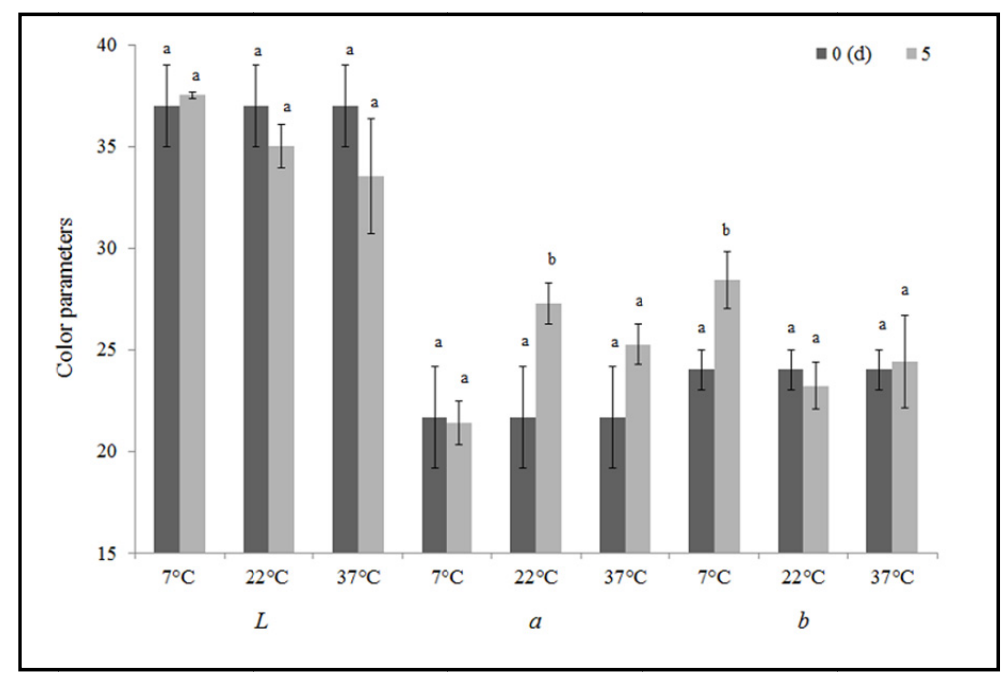

Figure 1. Change of color parameters in tomato during the storage at different conditions

\subsection{Firmness}

The firmness and crispness in vegetables are critical quality factors (Ochoa-Velasco \& Guerrero-Beltrán, 2014); during the postharvest is very important that the storage conditions are adequate to maintain the firmness of tomatoes. During the ripening and storage, the loss of firmness in tomatoes is because the actions of different enzymes like cellulase, pectinesterase, and polygalacturonase on cell wall, media lamella, and plasmatic membrane (Tucker, Robertson, \& Grierson, 1980; García \& Barrett, 2002). The polygalacturonase is the principal responsible of the softening in tomatoes due to this enzyme is synthesized of novo and increases during the ripening. Figure 2 presents the firmness of tomatoes during the storage at different conditions. It was observed that increasing the temperature of storage decrease the firmness of tomato. This is probably because increasing the storage temperature increases the metabolism of tomatoes, accelerating senescence process such as the loss of firmness (Peet \& Bartholemew, 1996). Moreover, the synthesis of polygalacturonase could be diminished at low temperature (Aguayo, Escalona, \& Artés, 2004). De Castro et al. (2005) reported that during the storage ( 8 days) of tomato cv Santa Clara at 14 and $24^{\circ} \mathrm{C}$, the firmness were 7.4 and 5.0 N, respectively.

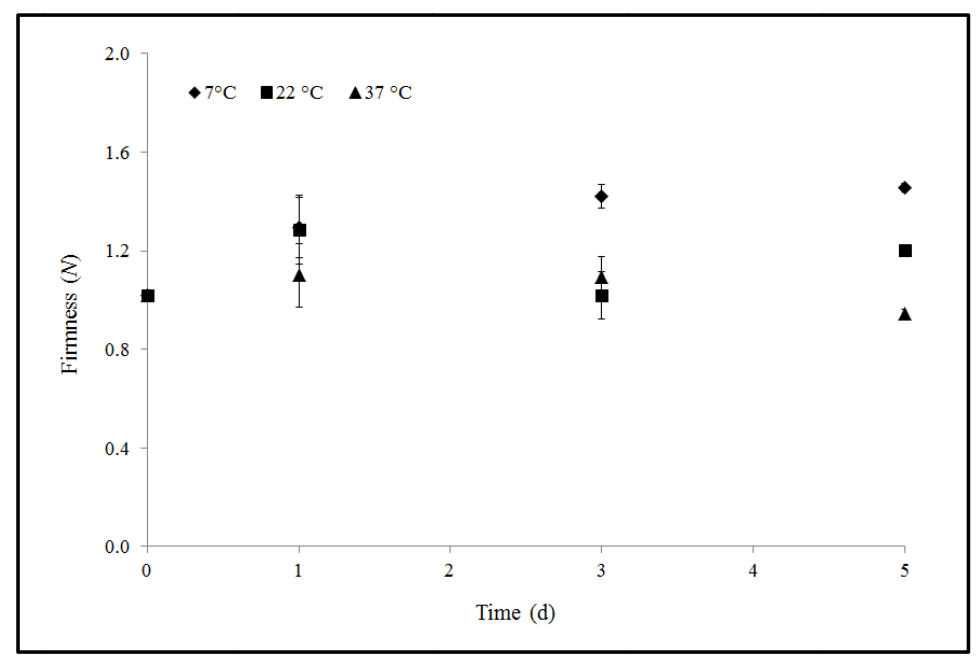

Figure 2. Firmness of tomato during the storage at different conditions 


\subsection{Ascorbic Acid}

Table 2 presents the vitamin $\mathrm{C}$ (ascorbic acid) contents of tomatoes during the storage at different conditions. At the beginning of the storage, the vitamin $C$ content was $35.3 \pm 1.3 \mathrm{mg} / 100 \mathrm{~g}$ of fresh weight (FW). During the storage it was observed a significantly increase $(\mathrm{p}<0.05)$ of the vitamin $\mathrm{C}$ in tomatoes stored at 7 and $37^{\circ} \mathrm{C}$, while in tomatoes stored at $22{ }^{\circ} \mathrm{C}$ the vitamin $\mathrm{C}$ decreased significantly $(\mathrm{p}<0.05)$ at day 5 of storage. Palop, Özdikicierler, Köstekli, Escriva, Esteve, and Frígola (2010) pointed out that during the refrigeration storage of tomatoes (Pera variety), the vitamin C was increased (20\%) for 6 days of storage. Zapata, Gerard, Davies, \& Schvab (2007) reported that the synthesis of vitamin C in tomatoes were higher in those grown in the months of highest average temperature. Moneruzzaman, Hossain, Sani, and Saifuddin (2008) reported that the ascorbic acid decreased with the ripening of tomato fruits; also during the storage at $30 \pm 1{ }^{\circ} \mathrm{C}$ the ascorbic acid decreased in $20 \%$ after 6 days of storage. It is known that ascorbic acid decreases with increase in temperature (Emese \& Nagymate, 2008); however, Oyetade, Oyeleke, Adegoke, and Akintunde (2012) performed an experiment of the stability of ascorbic acid from different sources (laboratory grade, pharmaceutical tablets, and grape juice) storage at different temperature $\left(4-5{ }^{\circ} \mathrm{C}\right.$, room temperature, and $\left.35{ }^{\circ} \mathrm{C}\right)$. They reported that the reduction of ascorbic acid was higher at room temperature in grape juice.

\subsection{Lycopene}

Table 2 shows the lycopene content of tomatoes stored at different condition. At the beginning of the storage, the lycopene content was $24.5 \pm 2.8 \mathrm{mg} / \mathrm{kg}$ of fresh weight $(\mathrm{FW})$. Similar results $(2.8 \pm 0.12 \mathrm{mg} / 100 \mathrm{~g})$ were obtained by Toor and Savage (2005) for the pulp of tomato; however, they found that the highest content of lycopene was in tomato skin $(8.7 \pm 1.1 \mathrm{mg} / 100 \mathrm{~g})$. According to Shi and Le Maguer (2000) the lycopene constitutes the $80-90 \%$ of the total pigments present in tomatoes. During the storage it was observed a significantly $(\mathrm{p}<0.05)$ increase of lycopene content in tomatoes stored at $22{ }^{\circ} \mathrm{C}(31.7 \pm 1.5)$. While at 7 and $37{ }^{\circ} \mathrm{C}$ the lycopene content increased at the beginning of the storage ( 1 day) but decreased at the end. The synthesis of lycopene can be affected by the temperature; at temperature below to $12{ }^{\circ} \mathrm{C}$ and above of $32{ }^{\circ} \mathrm{C}$ the lycopene precursors are inhibited (Abushita, Hebshi, Daood, \& Biacs, 1997). Fraser, Truesdale, Bird, Schuch, and Bramley (1994) pointed out that during the ripening of tomato the pigments change from xanthophylls in green fruits to lycopene, phytoene, fitofueno, $\beta$, and $\gamma$ carotenes in mature fruits. However, during the ripening, the highest concentration of pigments are found in the outermost tissues and decreased in the internal tissue (López-Casado, Matas, Cuartero, Heredia, \& Romero-Aranda, 2003).

\subsection{Chlorophylls and Carotenoids}

The carotenoids have a lot of biological function in human body, such as provitamin A activity, protect low density lipoproteins (LDL) against oxidation, scavengers activity against free radicals, tumor-suppressive activity, carcinogenesis, and protection of DNA against peroxidation (Voutilainen, Nurmi, Mursu, \& Rissnaen, 2006). However, only provitamin A activity has been demonstrated in the physiology of humans. Table 2 presents the chlorophylls $a$ and $b$, and the total carotenoids content of tomatoes during the storage at different conditions. It was observed that the chlorophyll $a$ and $b$ decreased during the storage, being significantly $(\mathrm{p}<0.05)$ at 22 and $37^{\circ} \mathrm{C}$. During the storage, the total carotenoids increased with a concomitant decrease in chlorophylls. However, at the storage temperature of $7{ }^{\circ} \mathrm{C}$, the synthesis of carotenoids from chlorophylls was limited ( 1 day) by the temperature. At the end of the storage, the total carotenoids content was significantly higher $(\mathrm{p}<0.05)$ in tomatoes stored at $22{ }^{\circ} \mathrm{C}$. During the ripening, the total carotenoids increased with a decrease of chlorophyll, reached the highest content of carotenes when the fruit was overripe (Fraser et al., 1994). It is important to note that the tomatoes storage at $22{ }^{\circ} \mathrm{C}$ presents the higher transformation of chlorophyll $a$ and $b$ in carotenoids, which indicate that the carotenoids production in tomatoes is affected by the temperature of storage (Arias et al., 2000). 
Table 2. Chlorophyll $a$ and $b$, lycopene, vitamin $\mathrm{C}$, and total carotenoids contents in tomato during the storage $\mathrm{a}^{\mathrm{a}}$

\begin{tabular}{|c|c|c|c|c|c|c|c|c|c|c|c|c|c|c|c|}
\hline \multirow[t]{2}{*}{ Time (d) } & \multicolumn{3}{|c|}{$\begin{array}{l}\text { Chlorophyll } a \\
(\mu \mathrm{g} / 100 \mathrm{~g} \mathrm{FW})\end{array}$} & \multicolumn{3}{|c|}{$\begin{array}{l}\text { Chlorophyll } b \\
(\mu \mathrm{g} / 100 \mathrm{~g} \mathrm{FW})\end{array}$} & \multicolumn{3}{|c|}{$\begin{array}{c}\text { Lycopene } \\
(\mathrm{mg} / \mathrm{kg} \mathrm{FW})\end{array}$} & \multicolumn{3}{|c|}{$\begin{array}{c}\text { Vitamin C } \\
(\mathrm{mg} / 100 \mathrm{~g} \mathrm{FW})\end{array}$} & \multicolumn{3}{|c|}{$\begin{array}{c}\text { Total carotenoids } \\
(\mu \mathrm{g} / 100 \mathrm{~g} \mathrm{FW})\end{array}$} \\
\hline & $7^{\circ} \mathrm{C}$ & $22^{\circ} \mathrm{C}$ & $37^{\circ} \mathrm{C}$ & $7^{\circ} \mathrm{C}$ & $22^{\circ} \mathrm{C}$ & $37^{\circ} \mathrm{C}$ & $7^{\circ} \mathrm{C}$ & $22^{\circ} \mathrm{C}$ & $37^{\circ} \mathrm{C}$ & $7^{\circ} \mathrm{C}$ & $22^{\circ} \mathrm{C}$ & $37^{\circ} \mathrm{C}$ & $7^{\circ} \mathrm{C}$ & $22^{\circ} \mathrm{C}$ & $37^{\circ} \mathrm{C}$ \\
\hline 0 & $63.2_{b}$ & $63.2_{a}$ & $63.2_{\mathrm{a}}$ & $112.1_{\mathrm{b}}$ & $112.1_{\mathrm{a}}$ & $112.1_{\mathrm{a}}$ & $24.5_{\mathrm{ab}}$ & $24.5_{\mathrm{c}}$ & $24.5_{\mathrm{c}}$ & $35.3_{b}$ & $35.3_{\mathrm{a}}$ & $35.3_{\mathrm{b}}$ & $39.2_{b}$ & $39.2_{\mathrm{d}}$ & $39.2_{\mathrm{c}}$ \\
\hline 1 & $91.0_{\mathrm{a}}$ & $33.8_{\mathrm{c}}$ & $44.2_{\mathrm{b}}$ & $176.4_{a}$ & $47.5_{b}$ & $77.3_{\mathrm{b}}$ & $28.2_{\mathrm{a}}$ & $21.0_{\mathrm{c}}$ & $50.3_{\mathrm{a}}$ & $32.3_{\mathrm{b}}$ & $32.7_{\mathrm{a}}$ & $28.7_{\mathrm{b}}$ & $33.4_{b}$ & $61.1_{\mathrm{c}}$ & $58.8_{\mathrm{b}}$ \\
\hline 3 & $83.2_{\mathrm{a}}$ & $48.8_{\mathrm{b}}$ & $44.2_{\mathrm{b}}$ & $110.7_{\mathrm{b}}$ & $57.1_{b}$ & $71.9_{\mathrm{b}}$ & $22.4_{\mathrm{ab}}$ & $48.7_{\mathrm{a}}$ & $41.2_{\mathrm{b}}$ & $36.6_{\mathrm{b}}$ & $36.7_{\mathrm{a}}$ & $42.8 \mathrm{a}$ & $99.0_{\mathrm{a}}$ & $81.6_{b}$ & $86.9_{a}$ \\
\hline 5 & $53.7_{\mathrm{b}}$ & $23.8_{\mathrm{c}}$ & $44.0_{\mathrm{b}}$ & $51.0_{\mathrm{c}}$ & $22.2_{\mathrm{c}}$ & $47.3_{\mathrm{c}}$ & $19.9_{\mathrm{b}}$ & $31.7_{\mathrm{b}}$ & $22.3_{\mathrm{c}}$ & $44.2_{\mathrm{a}}$ & $18.0_{\mathrm{b}}$ & $47.9_{\mathrm{a}}$ & $92.8_{a}$ & $118.7_{\mathrm{a}}$ & $74.2_{\mathrm{a}}$ \\
\hline
\end{tabular}

$\mathrm{a}$ Average $(\mathrm{n}=3)$. Different letters within the same column indicate significant difference $(\mathrm{p}<0.05)$.

\subsection{Antioxidant Activity}

Figure 3 presents the antioxidant activity of tomatoes storage at different condition. In tomatoes, the principal antioxidants compounds are carotenoids (lycopene), phenolic compounds, flavonoids, and vitamins like $\mathrm{C}$ and $\mathrm{E}$ (Beutner et al., 2001; Sahlin, Savage, \& Lister, 2004; Toor, Lister, \& Savage, 2005). In this study, the antioxidant activity was $126.9 \pm 0.2 \mu \mathrm{M}$ TEAC/100 g of tomato pulp. Toor and Savage (2005) informed values of 63 and 94 $\mu \mathrm{M}$ TEAC/100 g of tomato pulp for Tradiro and Excell cultivar, respectively. The antioxidant activity presents in pulp of tomato was lower to those obtained in skin and seed. Moreover, the hydrophilic extract presents significantly higher antioxidant activity to the lipophilic extract (Toor \& Savage, 2005). During the storage, the antioxidant activity did not change significantly $(\mathrm{p}>0.05)$, regardless the storage temperature. Zapata et al. (2007) reported that antioxidant compounds change during the marketing of tomato; increasing the content of lycopene and phenols; but decreasing the content of ascorbic acid.

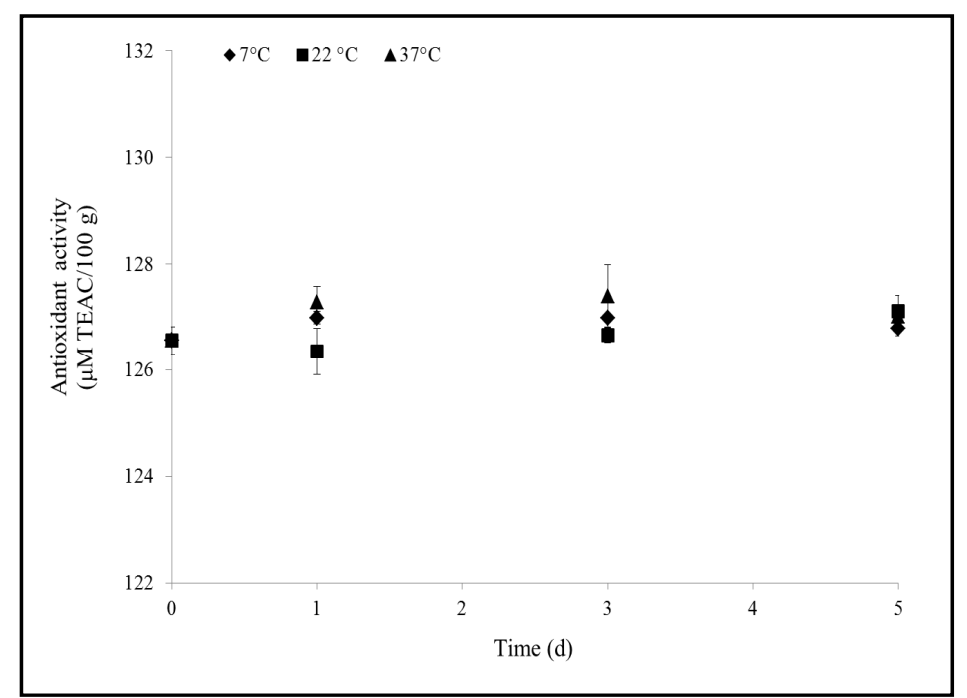

Figure 3. Antioxidant activity of tomato during the storage at different conditions

\subsection{Relationship Between Quality Factors}

Table 3 presents the Pearson correlation between $a$ and $b$ color parameters and some quality parameters of tomatoes. In tomatoes stored at $22{ }^{\circ} \mathrm{C}$ there was a high correlation $(>0.86)$ between the contents of carotenoids, vitamin $\mathrm{C}$, and antioxidant activity with the increase of red color. Arias et al. (2000) informed that in tomatoes ripened on plant (room temperature) presented a high concentration of antioxidant compounds and high development of red color. The lycopene did not have a good fitting between the $a$ and $b$ color parameters, regardless the temperature of storage. At $37^{\circ} \mathrm{C}$, there is a good fitting between the antioxidant components (except lycopene) and firmness with the $a$ color parameters. Moreover, in tomatoes stored at $7{ }^{\circ} \mathrm{C}$ it was observed that only vitamin $\mathrm{C}$ presents a high correlation with the $a$ color parameter and the $\mathrm{a} / \mathrm{b}$ index. Hart \& 
Scott (1995) informed that the antioxidant content of tomato depends of multiple factors, and some of them are the ripening stage and the storage temperature (Madhavi \& Salunkhe, 1998). However, Javanmardi and Kubota (2006) pointed out that low temperature reduce the lycopene contents, but increases the antioxidant compounds.

Table 3. Pearson correlation $(\alpha=0.05)$ between color parameters and quality parameters of tomatoes during the storage

\begin{tabular}{cccccccccc}
\hline \multirow{2}{*}{ Compounds } & \multicolumn{3}{c}{$7^{\circ} \mathrm{C}$} & \multicolumn{3}{c}{$2{ }^{\circ} \mathrm{C}$} & \multicolumn{3}{c}{$37^{\circ} \mathrm{C}$} \\
\cline { 2 - 9 } & $a$ & $a / b$ & $b$ & $a$ & $a / b$ & $b$ & $a$ & $a / b$ & $b$ \\
\hline Lycopene & -0.04 & 0.18 & -0.38 & 0.67 & 0.6 & -0.2 & 0.46 & 0.8 & -0.81 \\
Carotenoids & 0.41 & 0.01 & 0.62 & 0.96 & 0.97 & -0.86 & 0.8 & 0.64 & 0.33 \\
Vitamin C & 0.97 & 0.92 & 0.04 & 0.97 & 0.97 & 0.85 & 0.84 & 0.65 & 0.35 \\
Antioxidants & 0.65 & 0.03 & 0.69 & 0.86 & 0.9 & 0.97 & 0.87 & 0.89 & -0.3 \\
Firmness & -0.39 & -0.79 & 0.58 & -0.44 & -0.54 & 0.89 & 0.93 & 0.8 & 0.25 \\
\hline
\end{tabular}

\section{Conclusions}

During the postharvest of tomatoes occurs different change in the physicochemical characteristics and bioactive compounds that are affected by the storage temperature. The $a$ color parameter significantly increased at higher temperature of storage $\left(22\right.$ and $\left.37^{\circ} \mathrm{C}\right)$; moreover, the firmness increases as the storage temperature decrease. Color and firmness are critical factor for the acceptance of the consumers. At the end of the storage the higher values of lycopene (31.7 mg/kg FW) and total carotenoids $(118.7 \mu \mathrm{g} / 100 \mathrm{~g} \mathrm{FW})$ were observed in tomato stored at $22{ }^{\circ} \mathrm{C}$. However, the vitamin $\mathrm{C}$ was higher in tomato stored at 7 and $37{ }^{\circ} \mathrm{C}$, while the antioxidant activity did not change during the storage time. The bioactive compounds (carotenoids, vitamin $\mathrm{C}$, and antioxidant activity) present a high correlation with the development of the red color at the temperature of $22{ }^{\circ} \mathrm{C}$.

\section{Acknowledgements}

The authors thank the Program for the Improvement of Teaching, PROMEP (Project: 103.5/12/4310) for financial support of this research.

\section{References}

Abushita, A. A., Hebshi, E. A., Daood, H. G., \& Biacs, P. A. (1997). Determination of antioxidant vitamins in tomatoes. Food Chemistry, 60(2), 207-212. http://dx.doi.org/10.1016/S0308-8146(96)00321-4

Aguayo, E., Escalona, V. H., \& Artés, F. (2004). Metabolic behavior and quality changes of whole and fresh processed melon. Journal of Food Science, 69(4), 148-155.

AOAC. (2000). The Official Methods of Analysis. Washington, DC: Association of Official Analytical Chemists.

Arias, R., Lee, T. C., Specca, D., \& Janes, H. (2000). Quality Comparison of Hydroponic Tomatoes (Lycopersicon esculentum) Ripened On and Off Vine. Journal of Food Science, 65, 545-548. http://dx.doi.org/10.1111/j.1365-2621.2000.tb16045.x

Beutner, S., Bloedorn, B., Frixel, S., Blanco, H. I., Hoffmann, T., Martin, H. D., ... Walsh, R. (2001). Quantitative assessment of antioxidant properties of natural colorants and phytochemicals: carotenoids, flavonoids, phenols and indigoids. The role of $\beta$-carotene in antioxidant functions. Journal of the Science of Food and Agriculture, 81(6), 559-568. http://dx.doi.org/10.1002/jsfa.849

Crozier, A., Lean, M. E. J., McDonald, M. S., \& Black, C. (1997). Quantitative analysis of the flavonoid content of commercial tomatoes, onions, lettuce, and celery. Journal of Agriculture and Food Chemistry, 45(2), 590-595. http://dx.doi.org/10.1021/jf960339y

De Castro, L. R., Vigneault, C., Charles, M. T., \& Cortez, L. A. B. (2005). Effect of cooling delay and cold-chain breakage on "Santa Clara" tomato. Journal Food, Agriculture and Environment, 3(1), 49-54. Retrieved from http://world-food.net/effect-of-cooling-delay-and-cold-chain-breakage-on-santa-clara-tomato/

De Souza, A. L. B., Scalon, S. P. Q., Chitarra, M. I. F., \& Chitarra, A. B. (1999). Post-harvest application of $\mathrm{CaCl}_{2}$ in strawberry fruits (Fragaria ananassa Dutch cv. Segnoia): Evaluation of fruit quality and post-harvest life. Ciência e Agrotecnologia, 23(4), 841-848. 
Emese, J., \& Nagymate, P. F. (2008). The Stability of Vitamin C in Different Beverages. British Food Journal, 110, 296-309. http://dx.doi.org/10.1108/00070700810858709

FAO (Food and Agriculture Organization). (1979). Recommended practices for the prevention of mycotoxins in food, feed, and their products. Food Agric Organ UN Rome Italy, 51, 35-45. Retrieved from http://www.ncbi.nlm.nih.gov/pubmed/261952

Foyer, C. H., Rowell, J., \& Walker, D. (1983). Measurements of the ascorbate content of spinach leaf protoplasts and chloroplasts during illumination. Planta, 157, 239-244. http://dx.doi.org/10.1007/BF00405188

Fraser, P. D., Truesdale, M. R., Bird, C. R., Schuch, W., \& Bramley, P. M. (1994). Carotenoid Biosynthesis during Tomato Fruit Development'. Evidence for Tissue-Specific Gene Expression. Plant Physiolology, 105, 405-413.

García, E., \& Barrett, D. M. (2002). Preservative treatments for fresh-cut fruits and vegetables. Dept. Food Science and Technology. University of California, Davis.

Giovanelli, G., Lavelli, V., Peri, C., \& Nobili, S. (1999) Variation in antioxidant components of tomato during vine and post-harvest ripening. Journal of the Science of Food and Agriculture, 79, 1583-1588. http://dx.doi.org/10.1002/(SICI)1097-0010(199909)79:12<1583::AID-JSFA405>3.3.CO;2-A

Gómez, P. A., \& Camelo, A. F. L. (2002). Calidad postcosecha de tomates almacenados en atmósferas controladas. Horticultura Brasileira, 20, 38-43. http://dx.doi.org/10.1590/S0102-05362002000100007

Hart, D. J., \& Scott, K. J. (1995). Development and evaluation of an HPLC method for the analysis of carotenoids in foods, and the measurement of the carotenoid content of vegetables and fruits commonly consumed in the UK. Food Chemistry, 54, 101-111. http://dx.doi.org/10.1016/0308-8146(95)92669-B

Javanmardi, J., \& Kubota, C. (2006). Variation of lycopene, antioxidant activity, total soluble solids and weight loss of tomato during postharvest storage. Postharvest Biology and Technology, 41(2), 151-155. http://dx.doi.org/10.1016/j.postharvbio.2006.03.008

Kader, A. A., Stevens, M. A., Albright-Holton, M., Morris, L. L., \& Algazi, M. (1977). Effect of fruit ripeness when picked on flavor and composition in fresh market tomatoes. Journal of the American Society for Horticultural Science, 102(6), 724-731.

Ketsa, S., \& Wongveerakhan, A. (1987). The ascorbic acid content at maturity stages in tomato (Lycopersicon esculentum) cultivars. Thai Journal of Agricultural Science, 20, 257-261. Retrieved from http://www.thaiagj.org/index.php

Kubota, C., Thomson, C. A., \& Jamal Javanmardi, M. W. (2006). Controlled enviroments for production of value-added food crops with high phytochemical concentrations; Lycopene in tomato as an example, Hort Science, 41(3), 522-525. Retrieved from http://hortsci.ashspublications.org/content/41/3/522.full.pdf

Leonardi, C., Ambrosino, P., Esposito, F., \& Fogliano, V. (2000). Antioxidative activity and carotenoid and tomatine contents in different typologies of fresh consumption tomatoes. Journal of Agricultural and Food Chemistry, 48(10), 4723-4727. http://dx.doi.org/10.1021/jf000225t

Lichtenthaler, H. K., \& Wellburn, A. R (1983). Determinations of total carotenoids and chlorophylls a and b of leaf extracts in different solvents. Biochemical Society Transactions, 11, 591-592. Retrieved from http://www-06.all-portland.net/bst/011/0591/0110591.pdf

López-Casado, G., Matas, A. J., Cuartero, J., Heredia, A., \& Romero-Aranda, R. (2003). Mancha solar en el fruto de jitomate: análisis de carotenoides y estudio histológico. X Congreso Nacional de Ciencias Hortícolas. Pontevedra, España. Actas de Horticultura, 39, 401-403.

Madhavi, D. L., \& Salunkhe, D. K. (1998). Production, composition, storage, and processing. In D. K. Salunkhe \& S. S. Kadam (Eds.), Handbook of Vegetable Science and Technology (pp. 171-201). New York: Marcel Dekker.

Moneruzzaman, K. M., Hossain, A. B. M. S., Sani, W., \& Saifuddin, M. (2008). Effect of stages of maturity and ripening conditions on the biochemical characteristics of tomato. American Journal of Biochemistry and Biotechnology, 4, 336-344. http://dx.doi.org/10.3844/ajbbsp.2008.336.344

Mongkolsilp, S., Pongbupakit, I., Sae-Lee, N., \& Sitthithaworn, W. (2004). Radical scavenging activity and total phenolic content of medicinal plants used in primary health care. Journal of Pharmaceutical Science, 9, 32-35. Retrieved from http://www.researchgate.net/publication/228512535 
Ochoa-Velasco, C. E., \& Guerrero-Beltrán, J. A. (2014). Postharvest quality of peeled prickly pear fruits treated with acetic acid and chitosan. Postharvest Biology and Technology, 92, 139-145. http://dx.doi.org/10.1016/j.postharvbio.2014.01.023

Ogwulumba, S. I., Ugwuoke, K. I., \& Omemaramadu, R. (2011). Reaction of tomato cv Roma VF (Solanum lycopersicum) to meloidogyne javanica treub infestation in an ultisol treated with aqueous leaf extracts of bitter leaf (Vernonia amygdalina L.) and mango (Mangifera indica L). Journal of Plant Protection Research, 51,14-17. http://www.readcube.com/articles/10.2478/v10045-011-0003-2

Oyetade, O. A., Oyeleke, G. O., Adegoke, B. M., \& Akintunde, A. O. (2012). Stability studies on ascorbic acid (vitamin C) from different sources. Journal of Applied Chemistry, 2, 20-24.

Palop, S., Özdikicierler, O., Köstekli, M., Escriva, M., Esteve, M. J., \& Frígola, A. (2010). Ascorbic acid in tomatoes during refrigeration storage with absorbing sheet of ethylene. International Conference on Food Innovation. 25-29 de Octubre. Universidad Politécnica de Valencia. Retrieved from http://www.pdfio.com/k-7545816.html

Peet, M. M., \& Bartholemew, M. (1996). Effect of night temperature on pollen characteristics, growth, and fruit set in tomato. Journal of the American Society for Horticultural Science, 121, 514-519. Retrieved from http://etd.lib.ncsu.edu/publications/bitstream/1840.2/112/1/JASHS_96.pdf

Raffo, A., Leonardi, C., Fogliano, V., Ambrosino, P., Salucci, M., \& Gennaro, L. (2002). Nutritional value of cherry tomatoes (Lycopersicon esculentum Cv. Naomi F1) harvested at different ripening stages. Journal of Agricultural and Food Chemistry, 50, 6550-6556. http://dx.doi.org/10.1021/jf020315t

Sadler, G., \& Dezman, D. (1990). Rapid extraction of lycopene and carotene from reconstituted tomato paste and pink grapefruit homogenates. Journal of Food Science, 55, 1460-1461. http://dx.doi.org/10.1111/j.1365-2621.1990.tb03958.x

Sahlin, E., Savage, G. P., \& Lister, C. E. (2004). Investigation of the antioxidant properties of tomatoes after processing. Journal of Food Composition and Analysis, 17, 635-647. http://dx.doi.org/10.1016/j.jfca.2003.10.003

SAGARPA (Secretaría de Agricultura, Ganadería, Desarrollo Rural, Pesca y Alimentación). (2009). Programa de ejecución directa. Agricultura protegida. Retrieved from http://www.amhpac.org/contenido/plan\%20nacional\%20de\%20agricultura\%20protegida\%202009.pdf

Satyan, S. H., \& Patwardhan, M. V. (1983). Organic acid metabolism during ripening of fruits. Indian Journal of Biochemistry and Biophysics, 20, 311-314. Retrieved from http://www.sidalc.net/cgi-bin/wxis.exe/?IsisScript=UPEB.xis\&method=post\&formato=2\&cantidad=1\&expr esion $=\mathrm{mfn}=002550$

Shi, J., \& Le Maguer, M. (2000). Lycopene in tomatoes: Chemical and physical properties affected by food processing. Critical Reviews in Food Science and Nutrition, 40, 1-42. http://dx.doi.org/10.1080/10408690091189275

SIAP (Servicio de Información Agroalimentaria y Pesquera). (2012). Cierre de la producción agrícola por cultivo. Retrieved from http://www.siap.gob.mx/index.php?option=com_wrapper\&view=wrapper\&Itemid=350

Tigist, M., Workneh, T. S., \& Woldetsadik, K. (2013). Effects of variety on the quality of tomato stored under ambient conditions. Journal of Food Science and Technology, 50, 477-486. http://dx.doi.org/10.1007/s13197-011-0378-0

Toor, R. K., Lister, C. E., \& Savage, G. P. (2005). Antioxidant activities of New Zealand-grown tomatoes. International Journal of Food Sciences and Nutrition, 56, 597-605. http://dx.doi.org/10.1080/09637480500490400

Toor, R. K., \& Savage, G. P. (2005). Antioxidant activity in different fractions of tomatoes. Food Research International, 38, 487-494. http://dx.doi.org/10.1016/j.foodres.2004.10.016.

Toor, R. K., \& Savage, G. P. (2006). Changes in major antioxidant components of tomatoes during post-harvest storage. Food Chemistry, 99, 724-727. http://dx.doi.org/10.1016/j.foodchem.2005.08.049

Tucker, G., Robertson, N., \& Grierson, D. (1980). Changes in polygalacturonase isoenzymes during the ripening of normal and mutant tomato fruit. European Journal of Biochemistry, 112, 119-124. http://dx.doi.org/10.1111/j.1432-1033.1980.tb04993.x

USDA. (1997). United States Standards for Grades of Fresh Tomatoes. Retrieved from http://www.ams.usda.gov 
Voutilainen, S., Nurmi, T., Mursu, J., \& Rissnaen, T. H. (2006). Carotenoids and cardiovascular health 1-3. The American Journal of Clinic Nutrition, 83, 1265-1271. Retrieved from http://ajcn.nutrition.org/content/83/6/1265.full.pdf + html

Willcox, J. K., Catignani, G. L., \& Lazarus, S. (2003). Tomatoes and cardiovascular health. Critical Reviews in Food Science and Nutrition, 43, 1-18. http://dx.doi.org/10.1080/10408690390826437

Wills, R., Lee, T., Graham, D., McGlasson, W., \& Halls, E. (1981). PostHarvest: An Introduction of Physiology and Handling of Fruits and vegetables. London: Granada Publishing Ltd.

Wold, A. B., Rosenfeld, H. J., Holte, K., Baugerød, H., Blomhoff. R., \& Haffner, K. (2004). Colour of post-harvest ripened and vine ripened tomatoes (Lycopersicon esculentum Mill.) as related to total antioxidant capacity and chemical composition. International Journal of Food Science and Technology, 39, 295-302. http://dx.doi.org/10.1111/j.1365-2621.2004.00784.x

Zapata, L. M., Gerard, L., Davies, C., \& Schvab, M. C. (2007). Estudio de los componentes antioxidantes y actividad antioxidante en tomates. Ciencia, Docencia y Tecnología, 35, 175-193. Retrieved from http://www.revistacdyt.uner.edu.ar/

Žnidarčič, D., Dan, D., Oplanić, M., Karić, L., \& Požrl, T. (2010). Influence of postharvest temperatures on physicochemical quality of tomatoes (Lycopersicon esculentum Mill.). Journal of Food, Agriculture and Environment, 8, 21-25.

\section{Copyrights}

Copyright for this article is retained by the author(s), with first publication rights granted to the journal.

This is an open-access article distributed under the terms and conditions of the Creative Commons Attribution license (http://creativecommons.org/licenses/by/3.0/). 